\title{
DIE VERSPREIDING VAN DIE FRANSE HUGENOTE
}

\section{Kol dr Jan Ploeger*}

This article deals with the distribution of the French Huguenots over Europe and also South Africa after the revocation of the Edict of Nantes. Their profound influence on the communities they entered especially in the religious field, is specifically stressed.

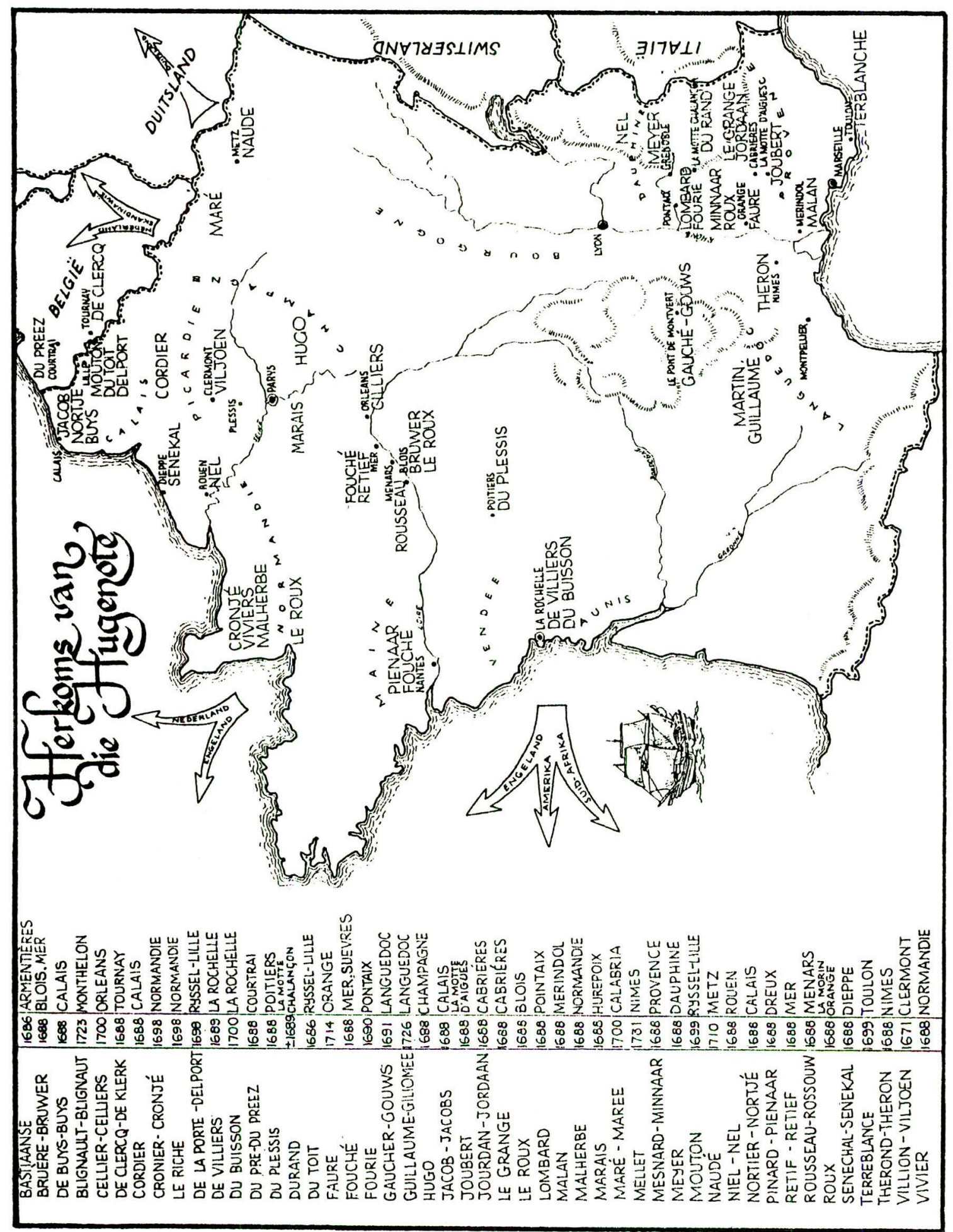


In 1988, die Hugenotefeesjaar hier te lande, is daar op 6 April by Saldanha, waar die eerste Hugenote voet aan wal gesit het, met die feesvieringe begin. Die groot fees het op 13 April begin toe 'n omgeboude seiljag met nakomelinge van die eerste Hugenote, wat met die Voorschoten aangekom het, in Tafelbaai ontskeep het. Die opvarendes het in outydse drag hul opwagting gemaak. Op die aand van 14 April het die Staatspresident die fees geopen in die amfiteater van die Taalmonument. Die optog wat reeds vroeër in die vorm van ' $n$ koets en ' $n$ aantal waens van Kaapstad na Stellenbosch, Paarl en Wellington vertrek het, het op 15 April in Franschhoek aangekom. Die volgende dag is ' $n$ groot kermis gehou en op 17 April is die feesviering met ' $n$ erediens by die Hugenote monument afgesluit.

Dit is, in breë trekke, 'n oorsig van die feesvierings van 1988.

Sowel die eerste as die tweede eeufees in verband met die aankoms van die Franse vlugtelinge het sonder feesvierings verbygegaan.

In 1939 het die destydse voorsitter van die Sentrale Hugenote-feeskomitee, senator F.S. Malan, hom - saam met sy mede-komiteelede - beywer om op ' $n$ passende wyse herdenkingsplegtighede voor te berei.

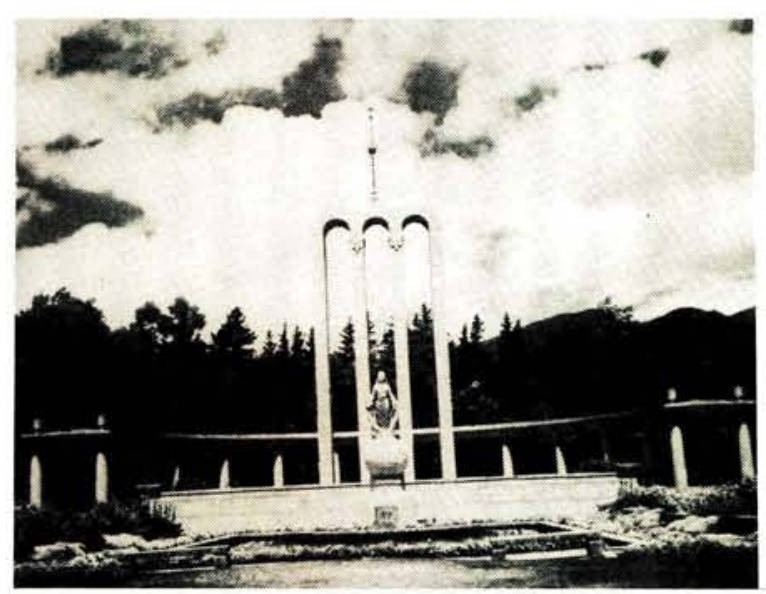

Die Hugenotemonument te Franschhoek

Op grond van die uitbreek van die Tweede Wêreldoorlog het senator Malan o.m. verklaar:

"Feestelikhede wat in die eerste plaas deur vermaaklikhede gekenmerk word, sou in die huidige toestand nie gepas wees nie, dog 'n diepe besef van die ellende waarin die wêreld andermaal gedompel is, hoef ons nie te belet om 'n gebeurtenis wat vir ons as volk van soveel betekenis is op plegtige wyse te gedenk nie."

Een van die kerns van hierdie verklaring is ongetwyfeld die beklemtoning van die groot betekenis van die onderhawige gebeurtenis. En in dié verband het senator Malan o.m. die volgende punte genoem:

(a) Die toevoeging van 'n nuwe ras-element by die bevolking van die Kaapkolonie deur die koms van die Hugenote.

(b) Die ineensmelting van die nuwe aankomelinge met die reeds bestaande blanke bevolkingselemente.

(c) Die vryheidsin wat die Hugenote teen onderdrukking van hulle persoonlike vryheid van gedagte geopenbaar het, en

(d) Die onverdeelde liefde vir Suid-Afrika wat hulle, na hulle vestiging, aan die dag gelê het.

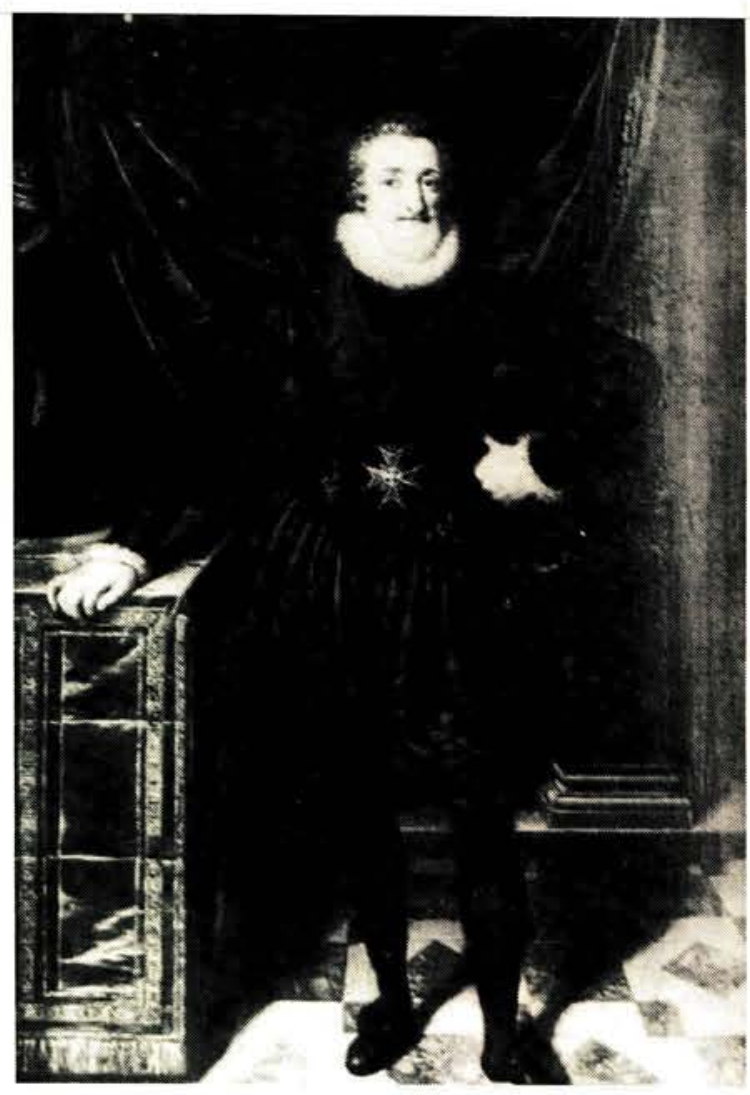

Die Hugenote leier Hendrik van Navarre wat die Franse troon in 1589 bestyg het om die eerste Bourbon Koning van Frankryk te word. Hy het die Edik van Nantes uitgevaardig in 1598 wat aan die Hugenote bepaalde regte verleen het en wat hulle teen vervolging beskerm het

Van die bekende historikus prof dr D.W. Krüger is die volgende gedagtes, uitgespreek in 1939 of 1940, afkomstig: 
"Uit die ongeluk wat die Hugenote getref het, het ook die verre Suid-Afrika voordeel getrek want in ons land met sy geringe blanke bevolking van daardie tyd het hulle, by die samestelling van die Afrikanernasie, 'n wesenlike element gevorm. Hulle het belangrike karaktereienskappe in Suid-Afrika voortgeplant en ons nasionale ontwikkeling gerugsteun... Op alle lewensterreine het manne met bekende Hugenote-name hul spore diep in Afrikaanse bodem afgedruk."

Hierdie aanhalings is, onderskeidelik, aan die Hugenote-nommer van Die Huisgenoot (15 September 1939) en die Gereformeerde Kerkalmanak van 1940 ontleen. Die uitsprake is kenmerkand van die erkentlikheid teenoor die Franse Hugenote en hulle nasate van die tydperk waarin die 250-jarige herdenking van die aankoms van die Kaapse Hugenote plaasgevind het.

Hierdie gedagtes en dié van die Franse skrywer Charles Weiss, van ongeveer 1850 , vertoon 'n merkwaardige ooreenkoms. In sy History of the French Protestant Refugees from the revocation of the Edict of Nantes to the present time (London, 1854) het hierdie skrywer o.m. beklemtoon dat die afstammelinge van die Franse Hugenote in die Kaapkolonie die moreel, die lewensgewoontes en die geloof in ' $n$ onbesmette vorm gehandhaaf het. En in 'n Engelse vertaling van sy Histoire de l'Afrique du Sud (1970), tw A History of South Africa (London 1977), het die Franse Skrywer Robert Lacour-Gayet o.m. getuig:

"The influence of the Huguenots was profound and is still evident today. It is not just a question of the techniques which they taught the colony... It is quite true that their religion was of a kind superior to that of the other immigrants. They had been shaped by their ordeal, and they had more than a touch of that intense, even fanatical faith which the English Puritans had brought to Americas sixty-eight years earlier. They thus contributed in large measure to the development of that spiritual toughness which was to ensure the survival of the Boers. They can also be seen as the ancestors of Afrikaner nationalism. They had cut themselves off from all links with their native land and, to an even greater degree than the Dutch, they came to regard South Africa as their country, their only country."

Uit hierdie oordele, afkomstig uit verskillende tydperke en opgeteken in verskillende tale, word dit o.m. duidelik dat Suid-Afrika gebaat het by die aankoms, vestiging en ontplooiing van die Franse Hugenote wat die geledere van bestaande blanke bevolking in die Kaapkolonie met ongeveer $20 \%$ versterk het.

Hierdie bydrae is bedoel om die belangstellende leser ' $n$ beeld te gee van die omstandighede waaronder die Hugenote hulle geboorteland verlaat het. Dit lei tot 'n poging om die omvang van hierdie grootskaalse uittog te bepaal. Nog vrae wat aandag vereis is waarheen die Hugenote uitgewyk het en watter bydraes hulle in dié lande gelewer het waar hulle gasvry ontvang is. Deur hierdie en ander vrae te probeer beantwoord, word die aankoms en vestiging van die Franse Protestante (Hugenote) aan die Kaap die Goeie Hoop teen 'n indrukwekkende agtergrond geplaas. Die agtergrond ontgaan die lesers wat hulle uitsluitend op die lotgevalle van die Protestantse vlugtelinge in ons land toespits.

\section{Die Edik van Nantes (1598-1685)}

$\mathrm{Na}$ ' $n$ agtal bloedige godsdiensoorloë tussen die Katolieke heersers en hulle aanhangers teen die Protestante (Hugenote) in Frankryk, het koning Hendrik IV in 1598 die laasgenoemde bevolkingsgroep ' $n$ aantal vrye stede in verband met hulle ombelemmerde geloofsuitoefening toegestaan. Tewens het die Hugenote verteenwoordiging in die Franse parlement ontvang. Hierdie koninklike besluite staan bekend as die Edik van Nantes (1598).

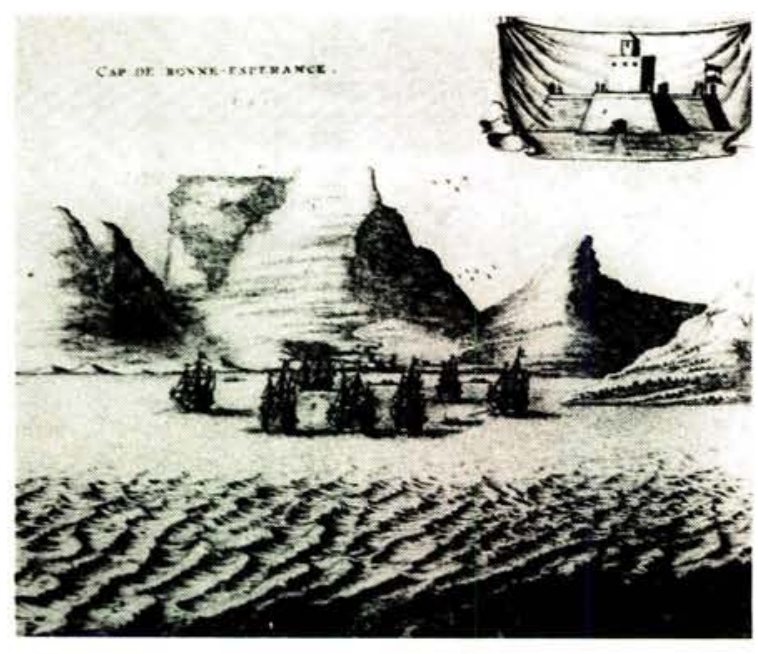

Die grootsheid van Tafelberg was die eerste gesig wat die Hugenote begroet het met hul aankoms by hulle nuwe vaderland

Tussen 1598 en 1685, die jaar waarin die edik herroep is, lê 'n drietal fases. In die eerste fase (tot 1629) lê die verowering van die genoemde 
vrye stede deur koninklike troepe. In 1629 het die laaste vrye stad, La Rochelle, in hande van die genoemde troepe geval en is die bestaande politieke voorregte kragtens die Edik van Alais ingetrek.

Van 1629 tot 1662 het die Hugenote as 'n groep bly voortbestaan wat oor sekere burgerlike en godsdienstige regte beskik het.

In 1662 het die eerste geloofvervolgings onder koning Lodewyk XIV begin. Hierdie fase het in 1685 met die herroeping van die Edik van Nantes geëindig.

Op 22 Oktober 1685 het die koning die herroepingsbesluite in Fontainebleau onderteken waarby o.m. ingesluit was: Die afbreek van die bestaande Protestantse kerkgeboue, die bevel om die uitoefening van die Protestantse geloof in woonhuise, kastele edm te staak, die opdrag aan leraars wat weier om tot die Katolieke geloof terug te keer om die land binne vyftien dae te verlaat, en die bepaling dat Protestantse skole gesluit moes word. Verder moes kinders van Hugenote-ouers van nou af deur priesters gedoop en in die Katolieke geloof opgevoed word. Dié Hugenote wat Frankryk reeds verlaat het, moes binne ' $n$ bepaalde tyd terugkeer, anders sou hulle besittings in beslag geneem word. $\mathrm{Hu}$ genote wat in Frankryk wou bly, is toegelaat om dit te doen en die hoop is uitgespreek dat die Here hulle mettertyd sou laat besluit om na die Katolieke Kerk terug te keer.

Daar was meer soortgelyke besluite. Die Protestantisme is, wat sy uitoefening aanboord van Franse skepe behels, verbied. Om Hugenote te help om aan boord van skepe na elders te vertrek, is strafbaar verklaar en die rykes moet Hugenote-bediendes deur Katolieke vervang.

Hierdie en ander besluite het aldus die historikus Charles Weiss verreikende gevolge gehad.

\section{Die uittog van die Hugenote}

Hugenote het besluit om die land te verlaat, maar aan verskeie van hulle is paspoorte geweier. In bepaalde gevalle, soos in dié van die bekende maarskalk Schomberg, is uitsonderinge gemaak. Maar hierdie toegewings en ander kwellende maatreëls was tevergeefs. Ten spyte van bewaking van die kusgebiede en die landgrense, wagposte by riviere en beloftes dat bewakers ' $n$ deel van die besittings van die oortreders sou ontvang, het die uittog voortgeduur.
Aangekeerdes is swaar gestraf, maar met of sonder gidse is Hugenote, soms in verskillende vorms van vermommings met of sonder hulle gesinne oor die land se grense. Ander is in Franse, Engelse en Nederlandse handelskepe die vryheid tegemoet.

Weiss het bereken dat, van ' $n$ totale Franse bevolking van 20 miljoen Katolieke en ' $n$ miljoen Hugenote tussen 250000 en 300000 Protestante hulle geboorteland verlaat het tussen die jare 1645 en 1700. Maar volgens dieselfde skrywer was dit onmoontlik om die juiste aantal te bepaal.

Die beroemde vestingboukundige Vauban het in 1688 aan die Minister van Oorlog, Louvois berig dat volgens hom 100000 militêre opgeleides na die buiteland vertrek het.

Die reeds genoemde Franse skrywer Robert Lacour-Gayet het die feit beklemtoon dat ' $n$ noukeurige weergawe van die landverlaters onmoontlik is. Hy het die aantal Protestantse vlugtelinge op 200000 tot 350000 geskat en verder gemeld dat 40000-60000 van hulle na die Nederlandse Republiek uitgewyk het. Daar moet onthou word dat reeds voor die herroeping van die Edik van Nantes in 1685 'n groot aantal Hugenote hulle in lande soos die Nederlandse Republiek, Engeland, Brandenburg (die latere koninkryk Pruise), Switserland en elders gevestig het, waar die Protestantisme in vryheid bely en verkondig is. Onder hierdie genoemde en ongenoemde lande het, aldus sommige skrywers, die Nederlandse Republiek en Brandenburg (Pruise) die eerste plek ingeneem.

In die loop van hierdie bydrae sal, met die oog op die verspreiding van die Hugenote in Europa en elders, verskillende state en destydse koloniale gebiede ter sprake kom. Kortliks sal ook aandag gewy word aan die beïnvloeding van die landbou, handel en nywerheid, die krygswese edm deur die Franse Protestantse vlugtelinge. Wat die verstrekte inligting betref, is hoofsaaklik van Charles Weiss se reeds genoemde publikasies gebruik gemaak.

\section{(a) Brandenburg (na 1701 die koninkryk Pruise)}

In Brandenburg het keurvors Frederik Willem $(1640-1688)$ in 1640 die troon bestyg. Deur oorlogsgeweld was sy land gedeeltelik ontvolk en verwoes, terwyl die handel en nywerheid gekwyn het. Die "Groot Keurvors" het vreemdelinge verwelkom om met die heropbou van sy 
land te help en hulle grond en geldelike hulp verstrek. Hy het hom ook tot die Franse Hugenote gewend en in Versailles het sy gesant Schwering Hugenote aangemoedig om na Berlyn oor te kom. Daar is die eerste Franse Protestantse kerkdiens in 1672 gehou, terwyl ander Hugenote-gemeentes o.m. in Magdenburg, Frankryk aan die Odev, Hallo, Spandau en Königsburg gestig is.

$\mathrm{Na}$ die herroeping van die Edik van Nantes het die keurvors op 26 Oktober 1685 die verklaring van Potsdam uitgereik, waarin Franse Hugenote verwelkom is. Deur vrystelling van belasting, ander toegewings, toetreding tot die gildes en die toekomstige verkryging van burgerregte het meer Hugenote na Brandenburg gekom. By elke Hugenote-nedersetting het 'n eie predikant Franse dienste gelei. In Amsterdam het agente van die keurvors belangstellende Hugenote van geld voorsien om na Hamburg te reis. Vandaar is hulle na Brandenburg gestuur, daar verwelkom en gehelp. Die Hugenote wat meer belang in handel en nywerheid gestel het, is deur die keurvors na die Nederlandse Republiek en Engeland gestuur. Omgekeerd het ander, wat eers in Switserland, die Nederlandse Republiek of Engelend gewoon en voorkeur aan Brandenburg gegee het, soontoe gegaan.

Militêre leiers van naam, Hugenote, het reeds voor 1685 in Brandenburgse diens oorgegaan. Onder hulle was genl maj Henri d'Hallard. Ongeveer 600 vroeëre Hugenote-offisiere het met onderskeiding die gapings opgevul wat gedurende die Dertigjarige oorlog (1618-1648) in die Brandenburgse krygsmag ontstaan het. Al hierdie beroepsoffisiere is bevorder en het, met 'n groot aantal Hugenote-manskappe in die geledere, nuwe regimente aangevoer. Ook het Hugenote-kadette na Brandenburg oorgekom (1685). Brandenburg het Franssprekende kapelane verkry en met voordeel van die koms van lede van die Hugenote-adel, leraars, regsgeleerdes, argitekte, handelaars, 'n aantal nyweraars, vervaardigers van klerasie, kouse, handskoene, hoede edm gebruik gemaak. Papiermeulens het ontstaan, die mynbou is verder ontwikkel en klokgieters, tuiniers en bloemiste is verwelkom.

En terwyl al hierdie immigrante ' $n$ behoorlike bestaan gevind het, het Hugenote-eenhede in Brandenburgse diens hulle gedurende die $\mathrm{Ne}$ gejarige oorlog (1689-1697) aan die gevegsfronte in Rynland, die Spaanse Nederlande, en Italië en o.m. by Fleurus (1690) onderskei. Ty- dens die Spaanse Opvolgingsoorlog (1701-1714), waarin Frankryk o.m. teenoor Engeland, die Nederlandse Republiek, Oostenryk en Pruise te staan gekom het, het Hugenote in Pruisiese militêre diens hulle by Landau (1702), Hochstadt (1703), Cassano (1705), Turyn (1706), Oudenaarde (1708) en Malplaquet (1709) onderskei.

Daar was ook Franse Hugenote in die Brandenburgse kolonies in Wes-Afrika.

Die besonderhede, wat vermeld is, is fragmentaries, maar voldoende om die belangrikheid van die Franse Hugenote in Brandenburg (Pruise) te beklemtoon.

In die $18 \mathrm{e}$ en die begin van die $19 \mathrm{e}$ eeu het die opkoms van die Pruisiese nasionaliteitsgevoel, die bloei van die Duitse taal en letterkunde en die anti-Franse reaksie van 1813-1814 die onvermydelike omvorming van die gemeenskap van die afstammelinge van die Franse Hugenote verhaas.

Reeds vroeër het van dié afstammelinge hulle vanne verander. Voorbeelde in die verband is: Lacroix - Krenz, Laforge - Schmidt, Duprés Wiese, Sauvage - Wild, of Boutémont - Buttmann.

\section{(b) Engeland, Skotland en lerland}

In die Britse koninkryk is, o.m. tydens die bewind van koningin Elizabeth (1558-1603), nie alleen asiel aan Franse Hugenote verleen nie, maar ook na die totstandkoming van die Edik van Nantes is dit as gevolg van godsdienstige en staatkundige oorwegings, as belangrik beskou om die Franse Hugenote in hulle eie land te help handhaaf.

Koning Jakobus I van Engeland (Jakobus VI van Skotland) (1603-1625) het hierdie beleid gehandhaaf. Tydens die latere regeringsjare van koning Karel I (1625-1649) het hierdie beleid ewenwel verflou. Oliver Cromwell (1649-1660) het die ou beleid in eer herstel. Nie alleen het Franse Hugenote ' $n$ veilige tuiste in Engeland gevind nie, maar dit was ook die geval met vroeë aanhangers van die Hervorming uit Noord-Nederland (die latere Nederlandse Republiek) en Suid-Nederland (die hedendaagse België). Vervolgde Nederlanders, Vlaminge en Franstalige Wale uit die suidelike deel van die destydse Spaanse Nederlande (vandag België) het na Engeland gevlug. Gevolglik was daar 


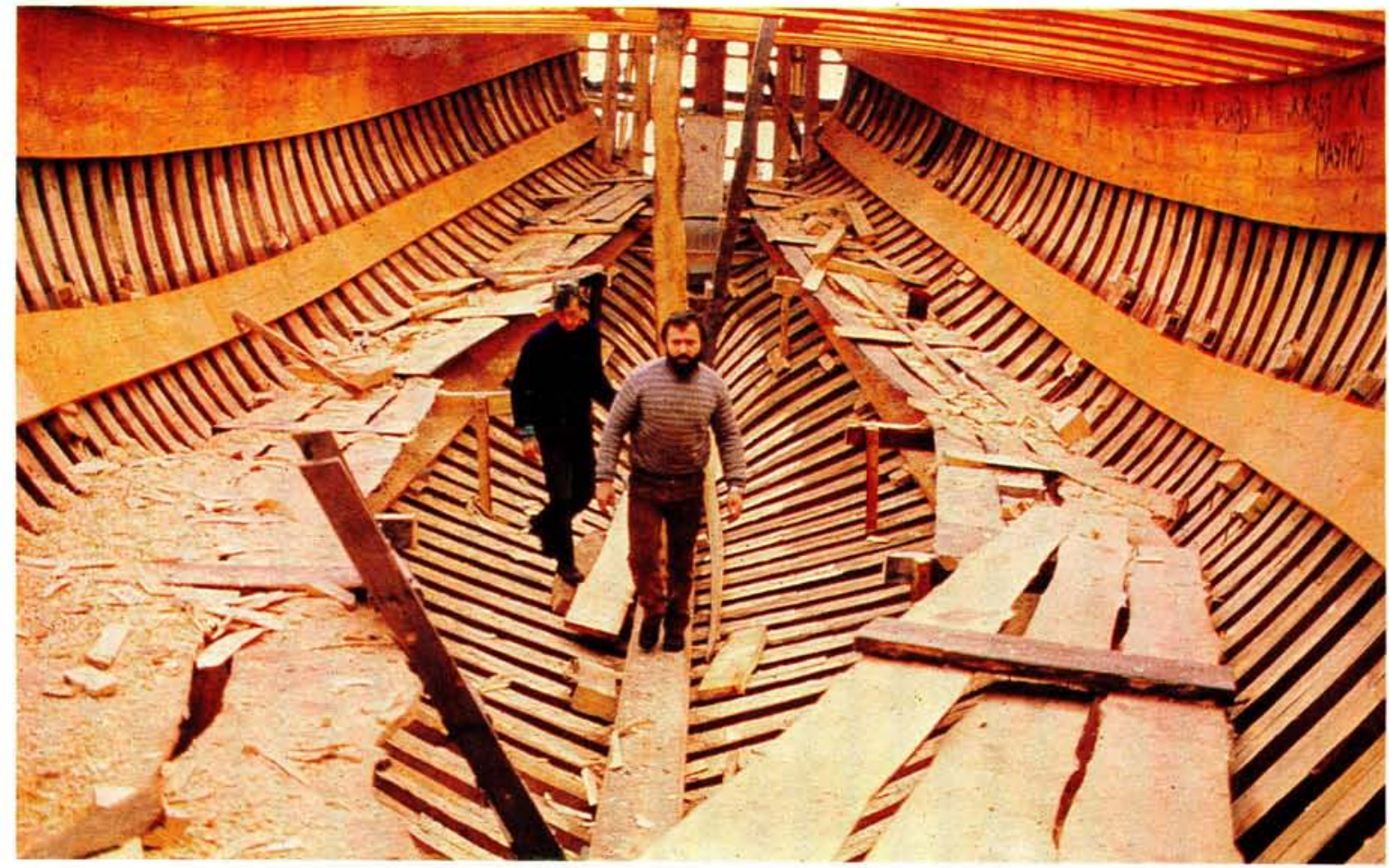

The replica caravel under construction in the shipyard of Samuel and Filhos in Vila do Conde near Oporto in Portugal. The vessel was designed by naval architects under the direction of Admiral Rogério S de Oliveira (Photograph: South African Panorama)

Die replika karveel onder konstruksie in die skeepswerf van Samuel en Filhos in Vila do Conde naby Oporto in Portugal. Die vaartuig is ontwerp deur vlootargitekte onder leiding van admiraal Rogério S de Oliveira (Foto: Suid-Afrikaanse Panorama)

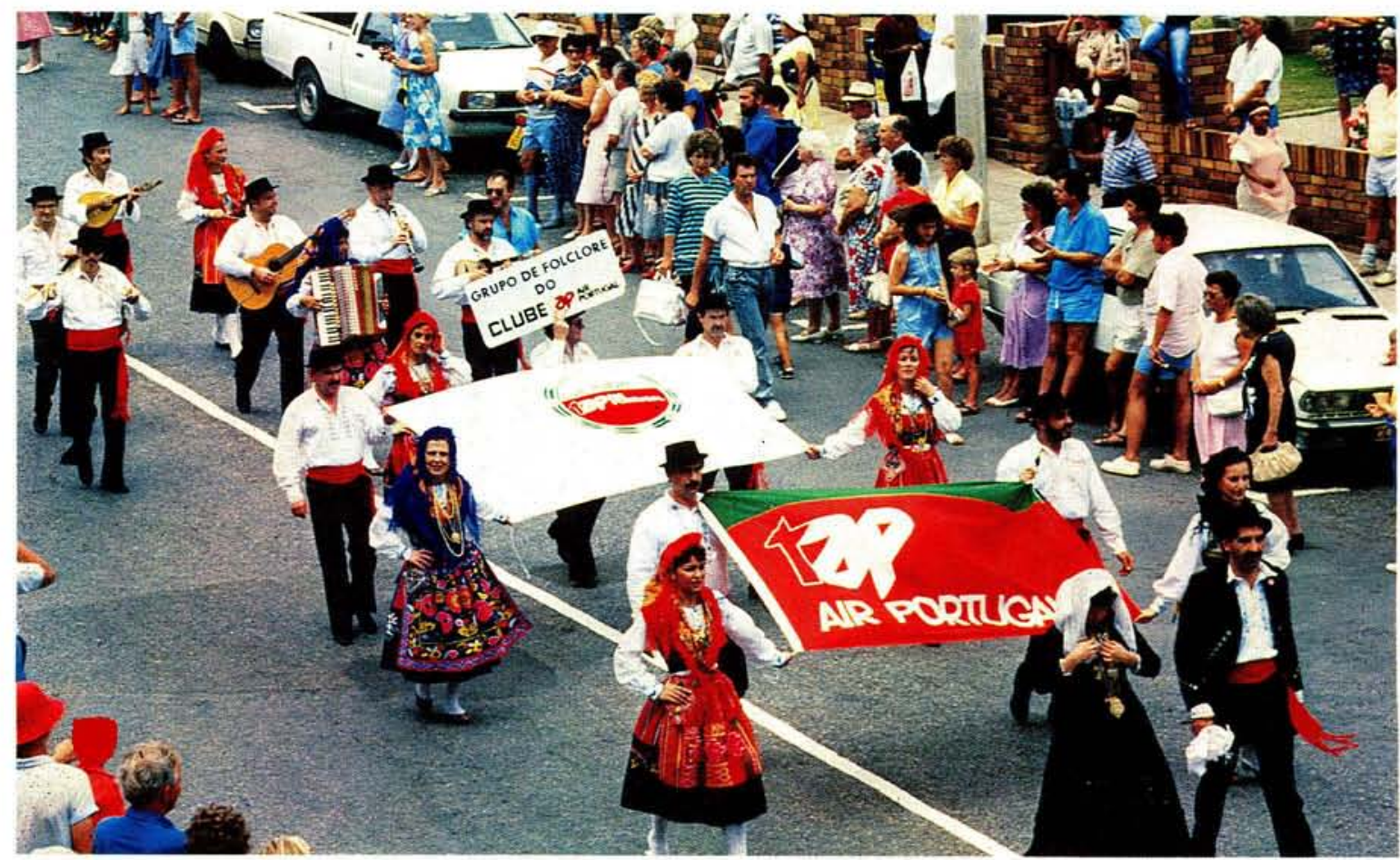

Dias Festival 1988. The Portuguese group in the streets of Mossel Bay

Dias Fees 1988. Die Portugese groep in die strate van Mosselbaai 


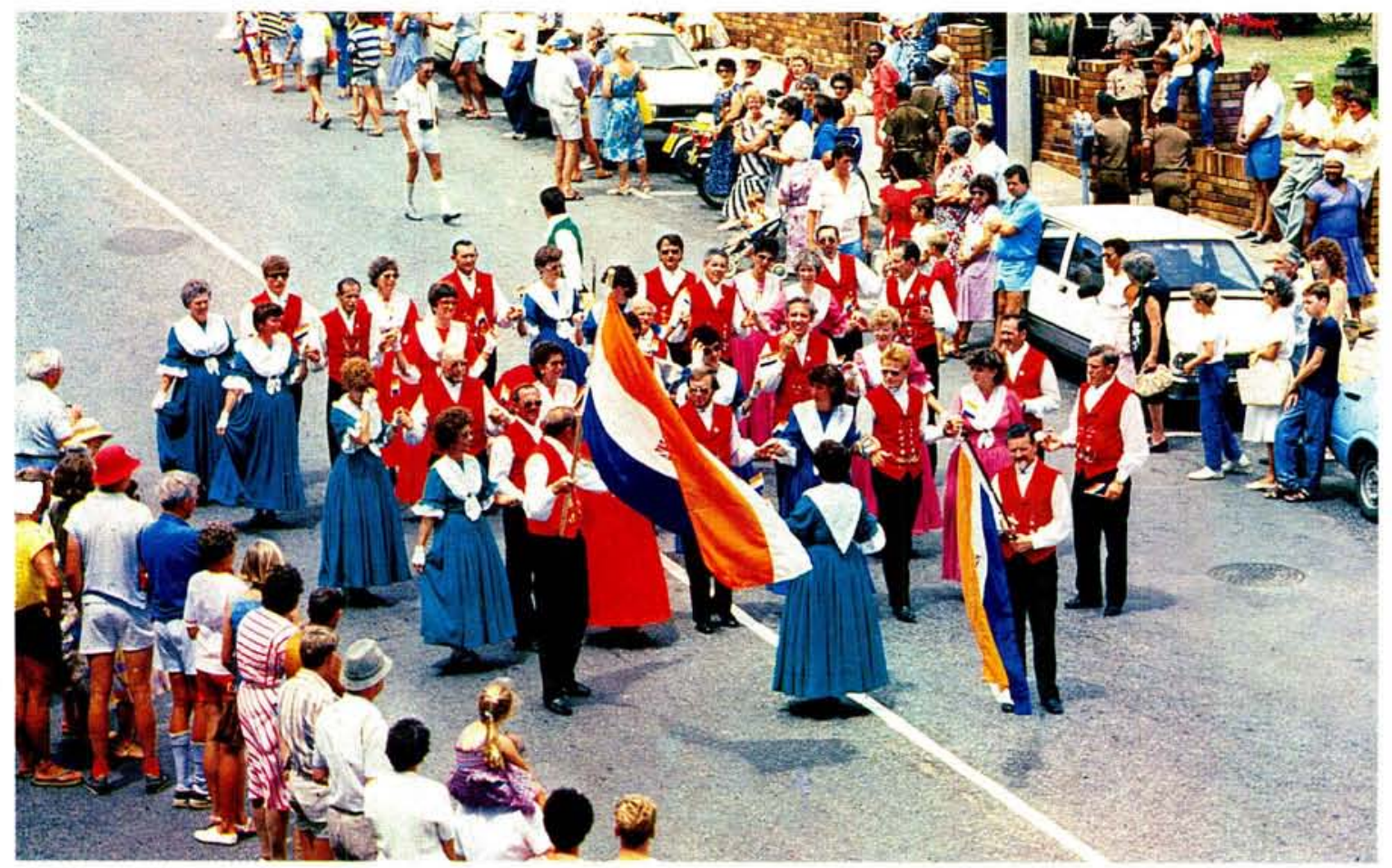

Die Suid-Afrikaanse groep loop deur die strate van Mosselbaai tydens die Diasfees

The South African group walking through the streets of Mossel Bay during the Dias festival

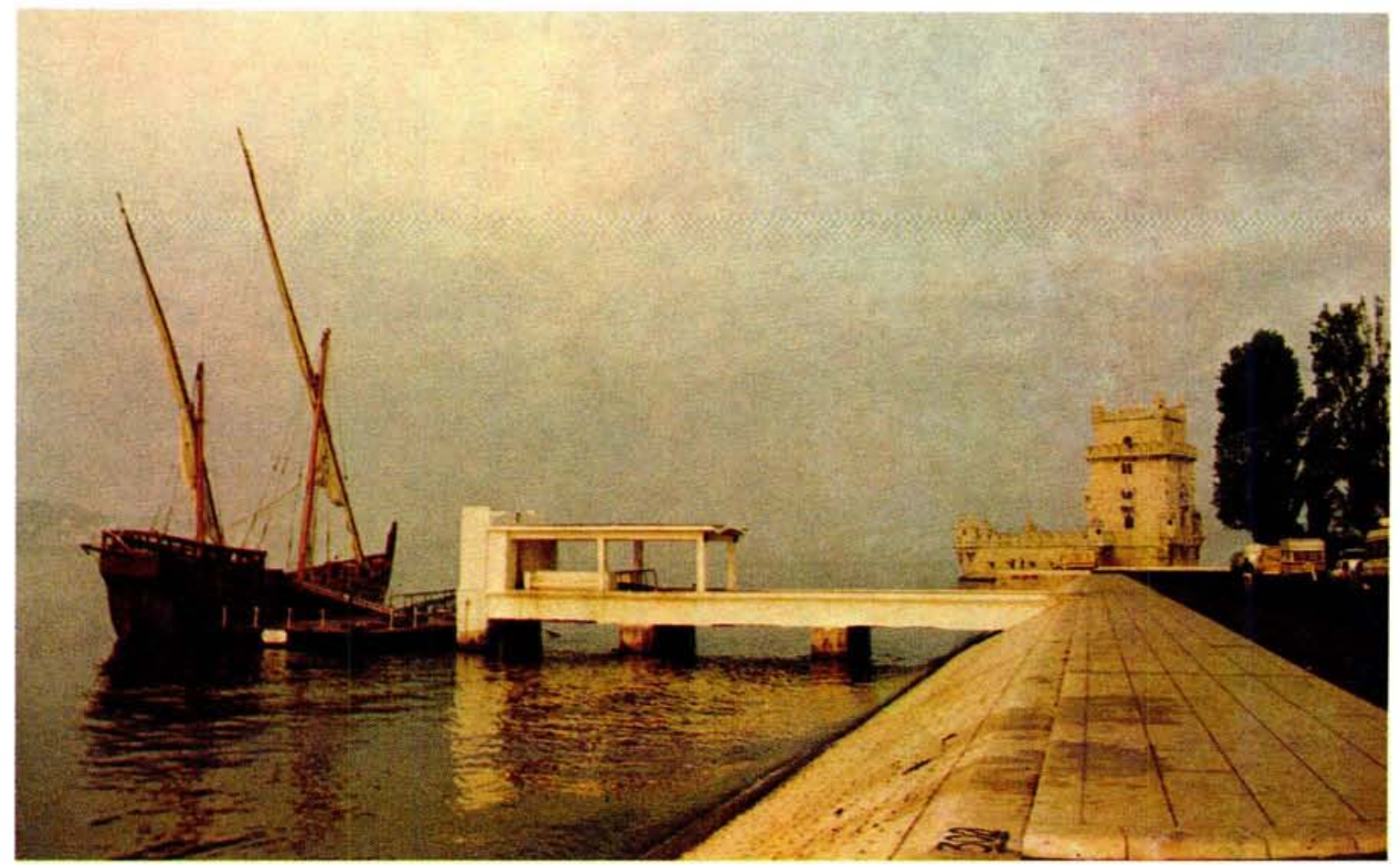

Die karveel geanker by die plek waarvan sy voorgangers vertrek het. Die Belem Toring vanwaar die Portugese koning sy seevaarders vaarwel toegewuif het op hulle reise gedurende die $15 d e$ eeu, kan regs op die foto gesien word

The caravel moored at the point where its ancestors departed from. The Torre de Belem, from where the Portuguese king saluted his seafarers farewell on their voyages during the 15th century, can be seen on the right 


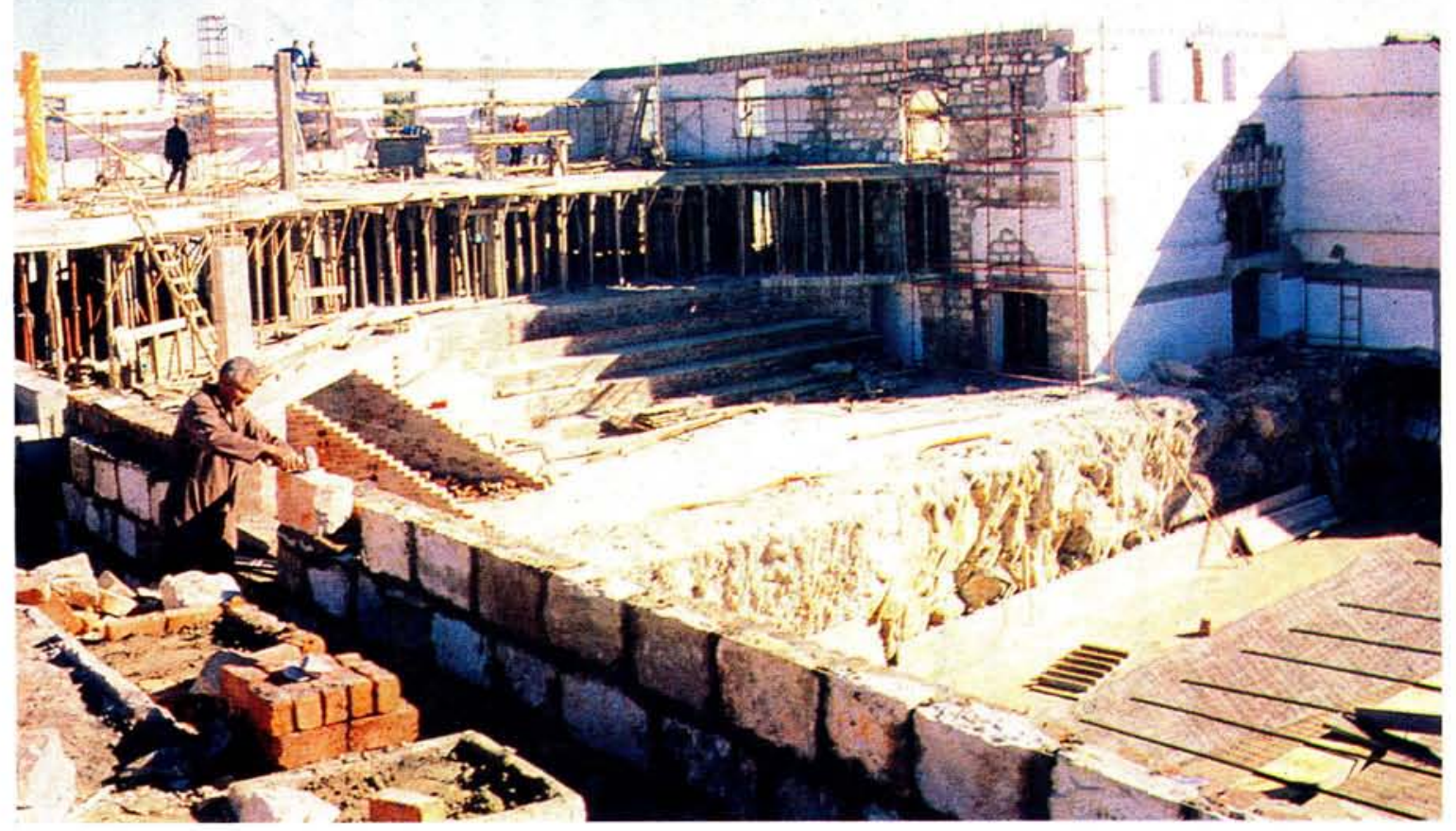

Restoration of the Old Mill at Mossel Bay to house the new maritime museum. In the foreground excavations are underway for space to house the replica caravel (Photograph: South African Panorama)

Restourasie van die Ou Meule by Mosselbaai om die nuwe maritime museum te huisves. Op die voorgrond word uitgrawings gedoen om plek te maak vir die plasing van die replika van die karveel (Foto: Suid-Afrikaanse Panorama)

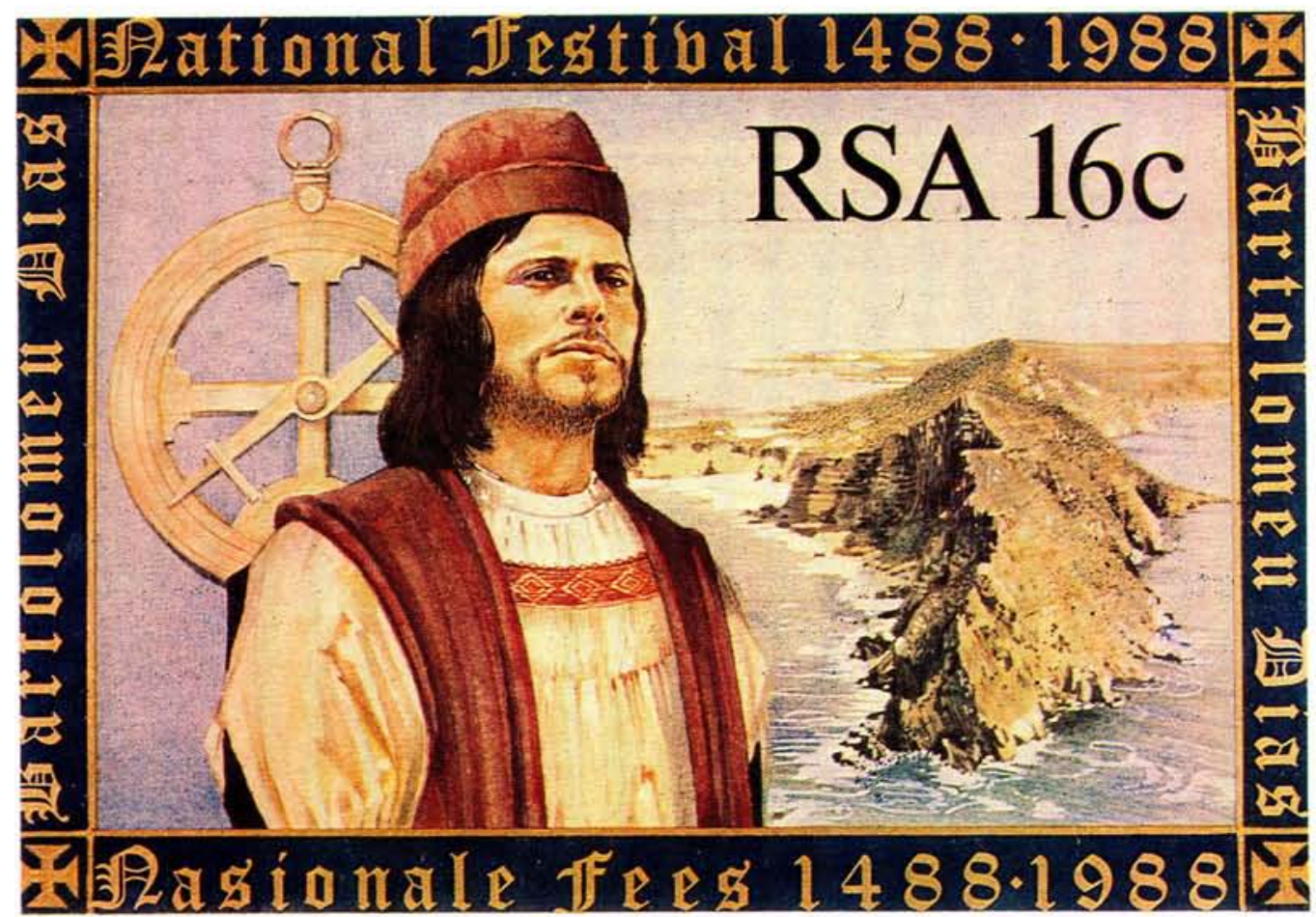

A likeness of Bartolomeu Dias, drawn by Cape Town artist Sheila Nowers, appears on one of the four commemorative stamps for the Dias celebrations in South Africa (Photograph: South African Panorama)

'n Afbeelding van Bartolomeu Dias, geteken deur die Kaapstadse kunstenares Sheila Nowels, verskyn op een van die vier gedenkseëls vir die Dias feesvieringe in Suid-Afrika (Foto: Suid-Afrikaanse Panorama) 


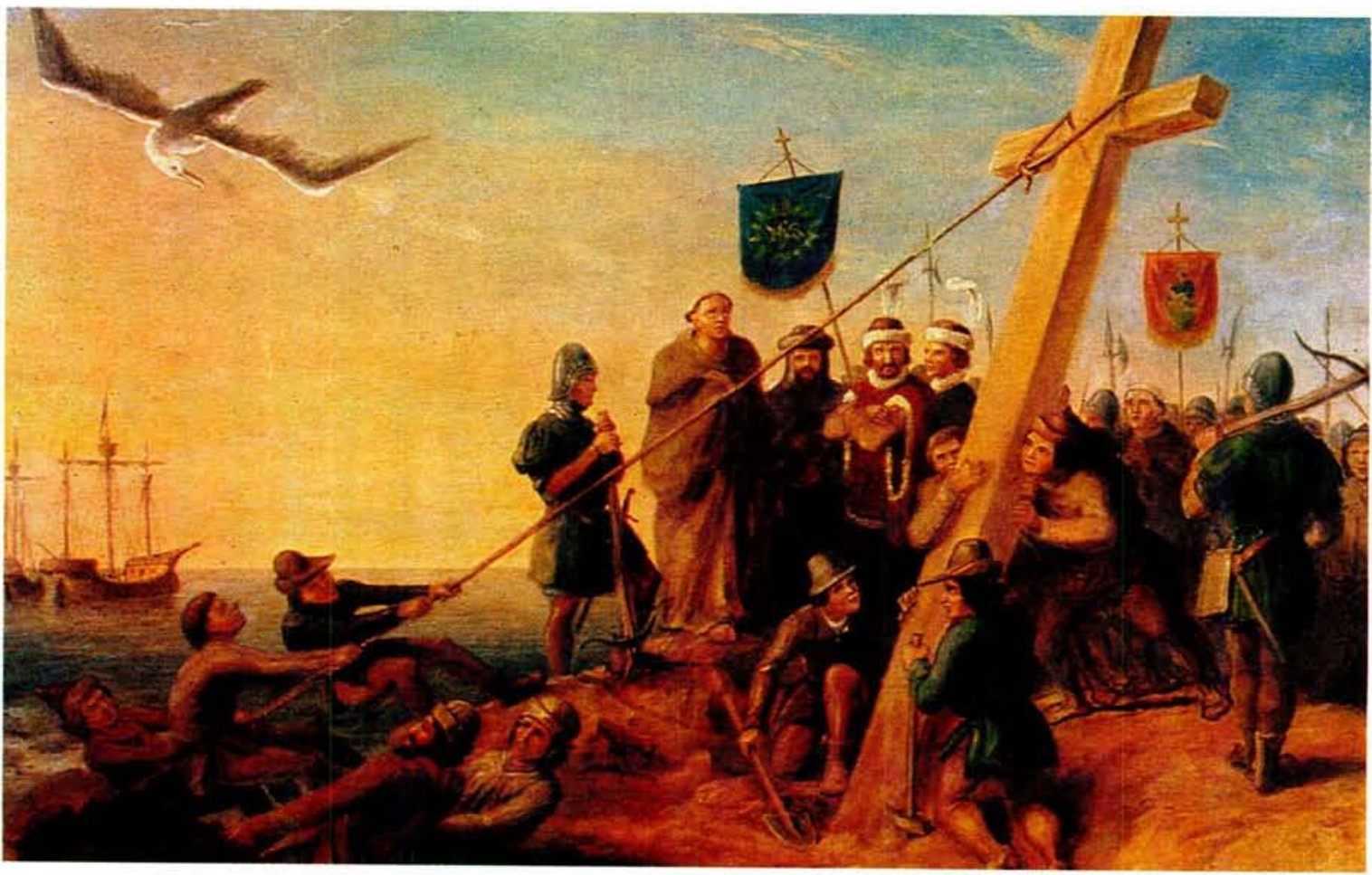
A painting of Dias planting a cross on the Island of St Croix, Algoa Bay in February 1488 (Photograph: South African
Panorama)

'n Skildery van Dias besig om ' $n$ kruis te plant op die Eiland van St Croix, Algoabaai in Februarie 1488 (Foto: SuidAfrikaanse Panorama)

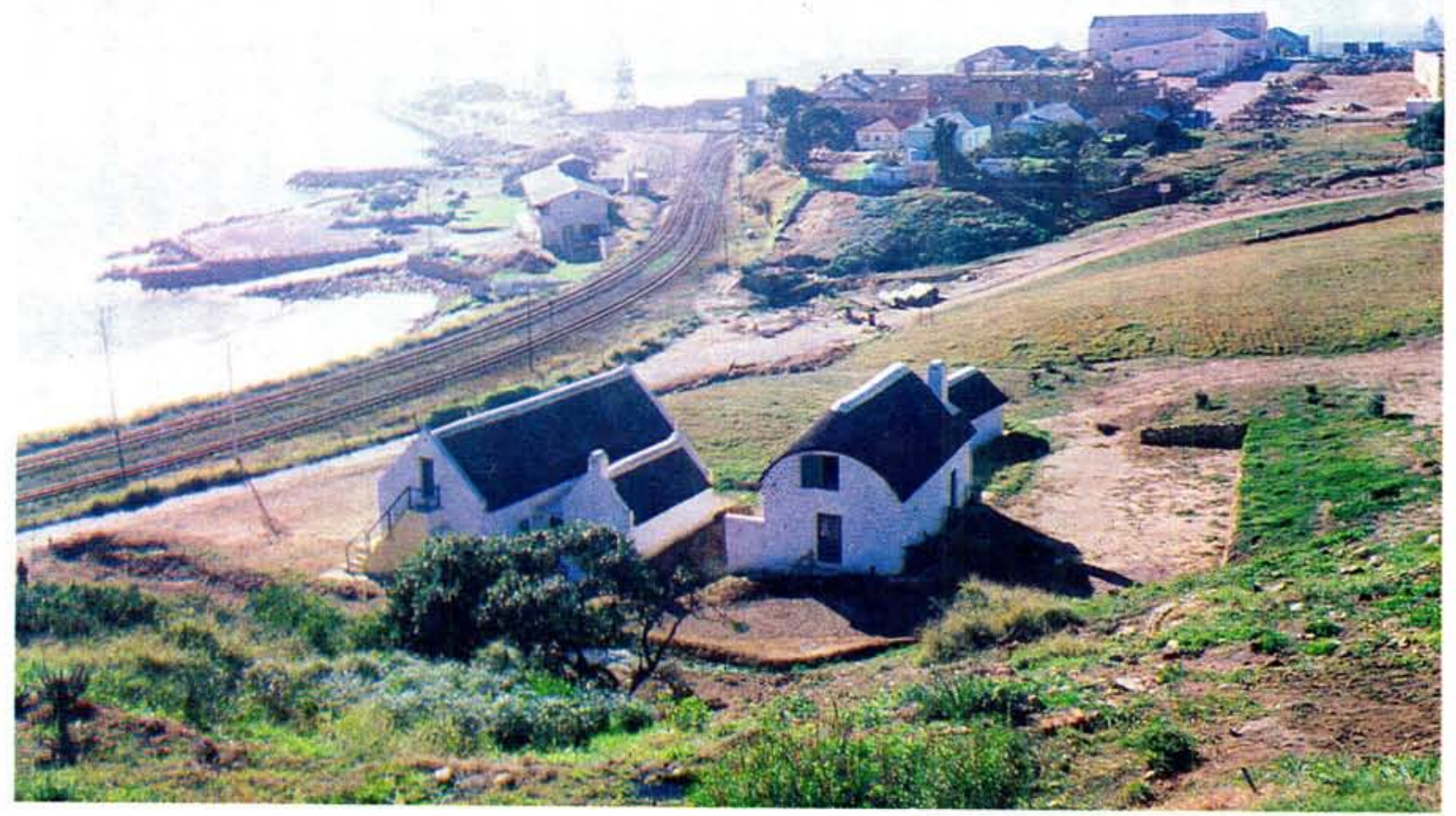

The bay where Dias first landed on South African soil at Sao Bras (later Mossel Bay) 500 years ago. In the foreground are the restored cottages of Alexander Munro (C 1830) (Photograph: South African Panorama)

Die Baai waar Dias die eerste keer aan wal gegaan het op Suid-Afrikaanse bodem by Sao Bras (later Mosselbaai) 500 jaar gelede. Op die voorgrond is die gerestoureerde huisies van Alexander Munro (C 1830) (Foto: Suid-Afrikaanse Panorama) 
reeds in 1550, kort na die stigting van 'n Nederlandstalige gemeente in Londen, 'n Franstalige kerk aanwesig. Voor 1685 was die vernaamste Waalse kerk in Engeland o.m. in Canterbury (1561) en Norwich (1564) (Franse Hugenote en Wale) aanwesig, terwyl Londen voor 1685 oor vier kerkgeboue vir Franssprekende Protestantse vlugtelinge beskik het.

Koning Karel II (1660-1685) het homself verplig gevoel om Protestante by te staan wat ter wille van hulle geloof vervolg is. Hy het Franse Hugenote die reg gegee om te naturaliseer en om ambagte uit te oefen. Sy opvolger, koning Jakobus II (Jakobus VII van Skotland) (1685-1688), het na die herroeping van die Edik van Nantes (1685) steun aan vervolgdes toegesê.

Weiss reken dat in 1695 ongeveer 80000 Franse Hugenote in Engeland woonagtig was. 'n Derde van hierdie vlugtelinge was in Londen gevestig. Hulle het by bestaande Franstalige Protestantse gemeentes aangesluit of nuwe gemeentes gestig en kerke gebou. Daar was ook Franse Hugenote in Skotland, terwyl na die val van koning Jakobus $\|$ in 1688 duisende in lerland gevestig is. Reeds in 1674 het van hulle in Dublin aangekom.

Nie al die vlugteling Hugenote kon in hulle eie behoeftes voorsien nie. In 1678 is 15000 Franse hulpbehoewendes in Engeland geldelik ondersteun. Van hulle is, deur die betrokke steunkomitee, 600 na die Britse kolonies gestuur. In 1688 het 27000 Hugenote steun ontvang en het koning Jakobus II probeer om van hulle na hulle land van herkoms terug te stuur. Die omwentelinge van 1688 en die troonbestyging van koning-stadhouer Willem III (1689-1702) en koningin Maria (1689-1694) het die einde van die genoemde pogings beteken.

Militêr beskou, het die Franse Hugenote stadhouer Willem III in sy stryd teen koning Jakobus II gesteun. Om die bekende "Glorious Revolution" van 1688 te bewerkstellig, is die stadhouer met ' $n$ ekspedisiemag van 11000 infanteriste en 4000 perde van die Nederlandse Republiek na Engeland. Onder dié krygsmag was daar die Hugenote-regimente, 'n Hugenote-eskadron ruitery en 736 vroeëre Franse Protestantse offisiere.

Dié krygsmag is deur maarskalk Frederik Armand de Schomberg, 'n Hugenoot van Duitse afkoms, in naam van Prins Willem III van Oranje aangevoer. In grootheid het Schomberg in die voetspore van Vondé en Turenne gevolg.

$\mathrm{Na}$ die vestiging van die nuwe gesag in Engeland is ' $n$ veldtog na lerland onderneem om oudkoning Jakobus II te verdrywe. Uitgeweke Hugenote-soldate van Genève en Lausanne is in die nuwe ekspedisiemag opgeneem en met 36000 troepe, van wie die helfte van Britse herkoms was, is die slag aan die Boyne in 1690 gelewer. Koning-stadhouer Willem II se mag het uit Britte, Franse Hugenote, Finne, Dene, Duitsers en 'n aantal Nederlandse kontingente bestaan. Weliswaar is die oorwinning behaal, maar Schomberg het aan die voorpunt van sy troepe gesneuwel. Hy was 82 jaar oud, maarskalk van Frankryk, hertog van Portugal, generaal van die Pruisiese troepe en 'n Britse hertog.

Hugenote het dus 'n waardevolle bydrae in verband met die vestiging van die gesag van koning-stadhouer Willem II en koningin Maria in die Britse ryk gelewer.

Duursamer was ewenwel die bydraes van Hugenote-nyweraars. Weiss skat dié groep saam met die onderskeie werkers, op 70000 . Hulle het in Engeland, Skotland en lerland die Britse handel en nywerhede sowel as die skeepvaart help ontwikkel en o.m. die vervaardiging van sy, linne, wandtapyte, hoede en papier ter hande te neem en op dié gebiede bydraes gelewer. Hulle het ook die kweek van blomme verfyn en veredel. Op wetenskaplike gebied is die Britse koninkryk met begaafde kanselredenaars, teoloë en skrywers verryk, terwyl die Hugenoot D. Papin stoom vir die aandrywing van skepe beproef het.

In die loop van die $18 \mathrm{e}$ eeu het die Hugenote geleidelik met die Engelse bevolking versmelt. Volgens Weiss het dié proses langsaam, maar aanhoudend verloop. In koning-stadhouer Willem III se tyd was daar 21 Hugenote-kerke in Londen, in 1782 nog 11. Heelwat afstammelinge van Hugenote het hulle name verander. So het Lemoûtre Masters, Lerou Krig, Tonnelier Cooper, Lejeune Young, Leblanc White en Lenoir Black geword. Volgens Weiss het die Franse kolonie in Londen omstreeks 1850 verdwyn.

\section{(c) Die Nederlande. Die Nederlandse Republiek}

Onder die Nederlande word dié grondgebied verstaan wat vandag die koninkryke Nederland en België omvat. In die eerste helfte van die sestiende eeu is hierdie gebiede aan die Spaan- 
se kroon toegevoeg. Staatkundige en godsdienstige faktore, t.w. die opkoms van die Protestantisme, het in 1586 tot die uitbreek van die Tagtigjarige oorlog (1568-1648) gelei. In hierdie stryd het na 1579 (die Unie van Utrecht) die noordelike Nederlande, die latere Nederlandse Republiek, die hoofrol gespeel. In 1648 het die oorlog ten einde geloop en het die jong Nederlandse republiek afhanklik van Spanje geword.

Vanaf die Middeleeue was die Nederlande reeds 'n toevlugsoord vir vlugtelinge uit alle dele van Europa. As gevolg van godsdienstwiste en oorloë in die sestiende en sewentiende eeu het veel meer vlugtelinge na Noord-Nederland uitgewyk as vroeër die geval was. Tydens die bewind van koningin Maria Tudor (1553-1558) het Protestantse Engelse na Noord-Nederland oorgekom, terwyl in die sewentiger en tagtiger jare van dieselfde eeu Protestantse Vlaminge en Wale (Franssprekendes) uit die reeds genoemde Suidelike Nederlande 'n veilige tuiste in die noorde gevind het.

Wale het kolonies in die toekomstige Nederlandse Republiek gevorm, nl. in Amsterdam (1579), Haarlem (1579), Middelburg (1579), Utrecht (1580), Leiden (1584) en Dordrecht (1589).

Franse Hugenote wat in 1585, ooreenkomstig 'n besluit van koning Hendrik III (1574-1589) aangesê is om hulle te bekeer of binne ses maande die land te verlaat, het hulle by die reeds genoemde Wale in Noord-Nederland aangesluit. $\mathrm{Na}$ die val van La Rochelle (1629) en voor die herroeping van die Edik van Nantes (1686) het Hugenote-leraars en geleerdes na NoordNederland vertrek. In 1681 het die dragonades, d.w.s. die verpligte inkwartiering van regeringstroepe in Hugenote-gesinne, weer 'n nuwe uittog veroorsaak. Deur die provinsiale bestuur van Holland en die stadsraad van Amsterdam is die aankomelinge vir bepaalde tydperke van die betaling van belasting vrygestel en is belowe om dié handelsprodukte, wat deur hulle vervaardig word, aan te koop. Behoeftiges is geldelik ondersteun.

$\mathrm{Na}$ die herroeping van die Edik van Nantes is soortgelyke maatreëls getref. Tydens die eerste jaar na die genoemde herroeping het meer as 250 Hugenote-leraars, wat gesalarieer is, in die Republieke aangekom. Stadhouer Willem III (1672-1702) het 'n tweetal Hugenote as hofpredikers aangestel. Vermoënde Hugenote het ook hul minder goed bedeelte geloofsgenote ge- steun. Ook deur die koms van welgestelde $\mathrm{Hu}$ genote, wat soms hulle eie handelskepe saamgeneem het, was daar kapitaal in oorvloed in die Republiek.

Wie was die immigrante? Reeds is 250 leraars genoem. Dan was daar Bybelvertalers, offisiere, ryk handelaars van Amiens, Rouen, Bordeaux en Nantes, tuiniers, kwekers en onderskeie soorte bekwame vakmanne.

Weiss het die totale instroming op 55000 geskat, van wie ongeveer 1700 ongeveer 15000 in Amsterdam gewoon het. Omstreeks 1715 het al hierdie Hugenote burgers van hulle nuwe vaderland geword.

Hugenote het invloed op die Nederlandse taal en onderwys uitgeoefen en in Franse geskrifte is nuwe gedagtes verkondig en versprei. In die Republiek was geen sensuur nie en daardeur is die verspreiding van nuwe gedagtes bevorder. Beroemde regsgeleerdes en denkers, letterkundiges e. a. het die Nederlandse geesteslewe verbreed en verdiep.

Op die gebied van handel en nywerheid het die Hugenote, o.m. in Amsterdam, vir die uitvoermarkte gewerk. Hoede, sy, suiker, vloermatte, goud- en silwerdraad is uitgevoer. Die bestaande walvisvaart na Groenland het uitgebrei. Papiersoorte is oor die lengte en breedte van Europa uitgevoer en drukkerye en uitgewerye van naam het gebloei. Die Hugenote-drukkersgeslag Huguetan (vader en drie seuns), van Lyon, het in Amsterdam wêreldvermaardheid verwerf. En soos ook in ander lande die geval was waar Hugenote-handelaars en nyweraars skouer aan die wiel gesit het, het die Franse uitvoermark na sekere lande aanmerklik kleiner geword.

Op die gebied van die krygswese en die diplomasie het Franse Hugenote en hulle afstammelinge ook in die Nederlandse Republiek ' $n$ rol van betekenis gespeel. In die Republiek het, net soos in die latere Nederlandse koninkryk name soos Boissevain en Labouchère ' $n$ bekende klank gehad. In die $18 \mathrm{e}$ eeu het die invloed van die Franse taal groot gebly. Andersyds het huwelike tussen Nederlanders en afstammelinge van Hugenote tot versmelting gelei. Ook is vanne soos die volgende verander: Leblanc De Wit, Dujardin-Tuin, - Van den Bogaard, Deschamp - Van de Velde, Dubois - Van den Bosch, Chevalier - Ruyter, Duprés - Van der 
Weyden, Corneille - Kraaij, Desmoulins - Van der Meulen, Dumont - Van den Berg, e.a.

In 1688 was daar 62 Waalse kerkgeboue in die Republiek, in 1817 het daarvan nog 21 en in 1843 nog ' $n$ sestal bestaan. Staatshulp is, op dié tydstip, nog verleen aan Waalse gemeentes in Amsterdam, Rotterdam, Den Haag, Leiden, Utrecht en Groningen.

Soos opgemerk kan word het die Waalse- en Hugenote-gemeentes onder die benaming van Waalse gemeentes saamgesmelt. Daar was altyd ' $n$ hegte band tussen die Oranjehuis en dié kerkgenootskap en op 17 November 1985 het koningin Beatrix van die Nederlande in Delft ' $n$ gedenkdiens bygewoon waar die feit dat die oorgrote deel van die Hugenote en hulle afstammelinge drie eeue in Nederland woonagtig was, op ' $n$ plegtige wyse in die vorm van ' $n$ dankdiens herdenk is.

\section{(d) Switserland}

In die land van die Hervormers Zwingli (Zürich) en Calvyn (Genève) het die Franse Hugenote in die sestiende eeu ' $n$ toevlugsoord gevind. Omstreeks 1620 het hierdie Protestante reeds hulle eie gemeente en kerkgebou in Basel besit.

Die grootste groep Franse Hugenote het reeds in dié tyd in Genève gewoon.

$\mathrm{Na}$ die afkondiging van die Edik van Nantes (1598) en die Wesfaalse vrede (1648) het die trek van Franse Hugenote na Genève, Basel, Schaffhausen, Bern en Zürich voorlopig afgeneem totdat die vervolgings in Frankryk toegeneem het. In 1685 het honderde Franse Hugenote in Switserland aangekom. ' $n$ Deel van hulle het gebly, ander het die trek na Duitsland en die Nederlandse Republiek voortgesit.

Switserland se bevolking is met 20000 Franse Hugenote vermeerder. Hulle het die bestaande land- en wynbou bevorder. Tuiniers het nuwe groente- en vrugtesoorte begin kweek en ander het die handel en nywerhede in die land van hulle gashere bevorder. Goud- en silwersmede het, net soos horlosiemakers, o.m. hulle bedrywe in Genève gevestig.

Op militêre gebied het Franse Hugenote saam met Switsers as huurtroepe in die buiteland opgetree en, waar nodig, die Protestantse deel van Switserland help verdedig. Hugenote het die Switserse vorm van die Franse taal op ' $n$ hoër peil help bring en die wetenskappe help bevorder. In 1685 was daar meer as 200 Hugenote-leraars in Switserland, waar ook - na verloop van tyd - die opleiding van Hugenote-predikante in Lausanne ter hand geneem is. In die Duitssprekende deel van Switserland, in stede soos Basel, Bern en Zürich, het die Hugenote en hulle afstammelinge in die loop van die $18 \mathrm{e}$ eeu geleidelik met die plaaslike bevolking begin versmelt.

\section{(e) Denemarke, Swede en Rusland}

Hierdie lande het, aldus Weiss, 'n geringe aantal Franse Hugenote aangetrek omdat hulle te ver van die sentrale deel van Europa verwyder was en nie veel bestaansmoontlikhede vir die genoemde vlugtelinge gebied het nie. Destyds was Denemarke en die huidige selfstandige koninkryk Noorweë onder 'n gemeenskaplike heerser. Hugenote-kolonies het in Kopenhagen en Altona ontstaan. In Altona het sedert 1582 Wale gewoon wat uit die Spaanse Nederlande gevlug het.

Die Franse emigrasie na Denemarke was hoofsaaklik op die gebied van die land se verdediging en die landbou toegespits. Die Hugenoot Frederic Charles de la Roche, graaf van Roxe en Rouci, was opperbevelhebber van die Deense troepe. Ook is die Deense vloot deur Franse Hugenote versterk.

In Swede het koning Karel XII (1697-1718) Hugenote aangemoedig om hulle in sy land te vestig, o.m. het ' $n$ paar honderd Hugenote, wat geen bestaan in die Nederlandse Republiek kon vind nie, deur bemiddelling van die republikeinse bewind na Swede oorgekom om daar grond te ontvang.

In verband met die koms van Franse Hugenote in Rusland het keurvors Frederik III van Brandenburg (1688-1701; koning van Pruise van 1701-1713) as bemiddelaar by die Russiese heerders tsaar Ivan $V$ en tsaar Peter (16821689 ) opgetree om toegang vir die vlugtelinge te verkry. In 1688 is belanghebbendes toegelaat en het ' $n$ Franse kolonie in die destydse Sint Petersburg ontstaan. Saam met aldaar wonende Engelse, Nederlandse, Switserse en Geneefse lidmate het die Hugenote oor 'n gemeente en 'n kerk beskik.

\section{(f) Amerika}

Reeds kort na 1550 het die bekende Franse admiraal Gaspard de Coligny (1519-1572), 'n 
vooraanstaande Hugenoteleier, planne beraam om van sy geloofsgenote in Brasilië te vestig. Dié plan het ewewel misluk. Daarna wou die admiraal, met toestemming van koning Karel IX (1560-1574), 'n Hugenote-nedersetting in Florida stig. Ook dié poging het skipbreuk gely.

In 1685 het Engeland aan die ooskus van NoordAmerika oor ' $n$ aantal kolonies beskik en reeds in 1662 Franse Hugenote na Massachusetts gestuur.

In die Nederlandse kolonie Nieuw-Nederland, met die hoofstad Nieuw-Amsterdam (later: New York) was, voor die oorgawe aan Engeland in 1664, na die Nederlanders die Hugenote die sterkste immigrantegroep.

Voor 1685 het Franse Hugenote tot vestiging in die kolonies Maryland en Noord- en Suid-Carolina oorgegaan. Honderde Hugenote het in Pennsylvanië en Virginia aangekom, maar volgens Weiss het Suid-Carolina die tuiste van die meeste Franse Hugenote in die Nuwe Wêreld geword. Die belangrikste middelpunt van hulle bedrywighede was Charleston.

Die Franse Hugenote het ' $n$ groot aandeel in die ontginning van die Engelse kolonies in NoordAmerika gehad. Hulle afstammelinge het skouer aan skouer met hul Engelse medelandgenote in die Sewejarige oorlog (1756-1763) geveg om in 1776 hulle volle gewig aan die kant van die Amerikaanse voorstanders van onafhanklikheid in te gooi. John Jay, John Bayard, John Louis Gervais en Henry Laurens was onder dié vryheidstryders wat, as afstammelinge van Franse Hugenote, louere in dié stryd verwerf het.

In die loop van die 18 e en die 19 e eeu het die afstammelinge van Franse Hugenote, net soos elders, met ander bevolkingselemente in Amerika versmelt. Hulle taal het verdwyn en volgens Weiss het hulle gemeentes by dié van die Presbiteriaanse Kerk aangesluit. In New York het aansluiting by die Anglikane plaasgevind en volgens Weiss het Charleston in omstreeks 1850 nog oor 'n Franse gemeente beskik wat die Franse gemeente in Londen as sy moedergemeente beskou het.

\section{(g) Suriname}

Aan die noordkus van Suid-Amerika lê die destydse Nederlandse kolonie Suriname. 'n Deel van dié gebied het aan goewerneur Francois van Aerssen (1683-1688) behoort. Hy het die immigrasie van Franse Hugenote uit die Nederlandse Republiek bevorder. ' $n$ Franse kerk het in Paramaribo tot stand gekom en die Franse $\mathrm{Hu}$ genote het veral die landbou (suiker) bevorder Pierre Saurin, 'n sendeling, het belangrike sendingwerk in die binneland van hierdie destydse kolonie verrig.

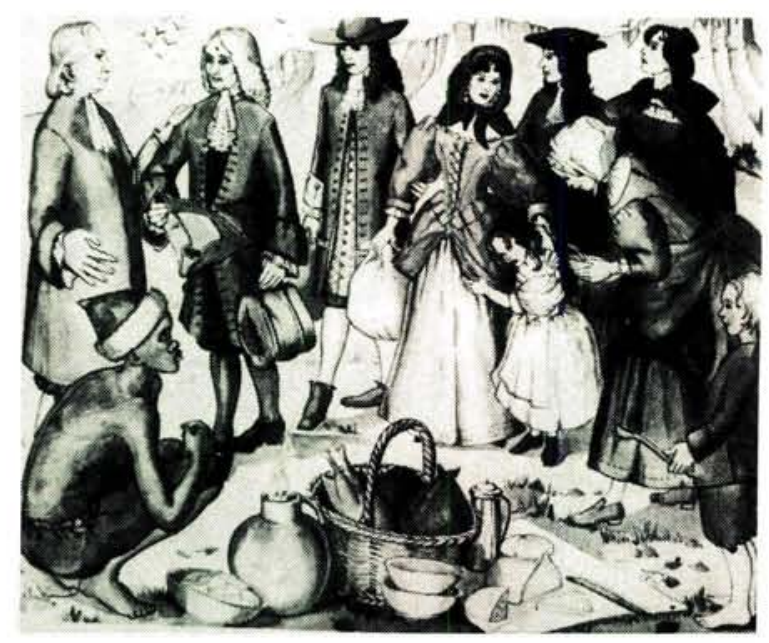

Die Hugenote arriveer haweloos in die Kaap aangesien hul al hul besittings in Europa moes agterlaat. Hulle is voorsien van basiese boumateriale en voedselvoorraad vir 'n paar maande

\section{(h) Die Kaapkolonie}

In breë trekke is, hoofsaaklik aan die hand van C. Weiss, die verspreiding van die Franse Hugenote oor verskeie lande in Europa en in die wêrelddeel Amerika beskryf.

In verband met die koms van die Franse Hugenote na die suidpunt van die wêrelddeel Afrika, na die destydse Kaapkolonie, bly Colin Graham Botha se studie Die Kaapse Hugenote (Kaapstad, 1939) nog altyd 'n betroubare gids.

Omstreeks 1948 het die reisiger-skrywer H.V. Mouton, in sy studie In search of South Africa (London 1948) na aanleiding van 'n besoek aan Franschhoek en die Hugenotemonument o.m. getuig:

"Among all the religious and political refugees who at one time or another left their own land, the Hugenots alone appear to have been welcomed everywhere and to have given their skill and their loyalty unquestioningly to the countries of their adoption."

En dieselfde skrywer vervolg sy siening met die volgende gedagte: 


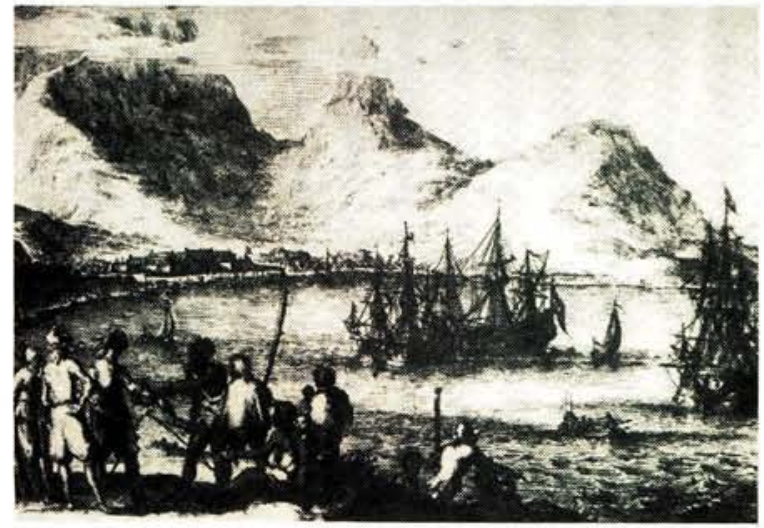

Die Tafelbaaise strand was teen die laat 1670's 'n miernes van aktiwiteit, maar die blanke nedersetting daar was nog maar baie klein

"Their arrival at the Cape was one of the fortunate moments in South African history. There were only about two hundred of them, but they have influenced South Africa out of all proportion to their numbers."
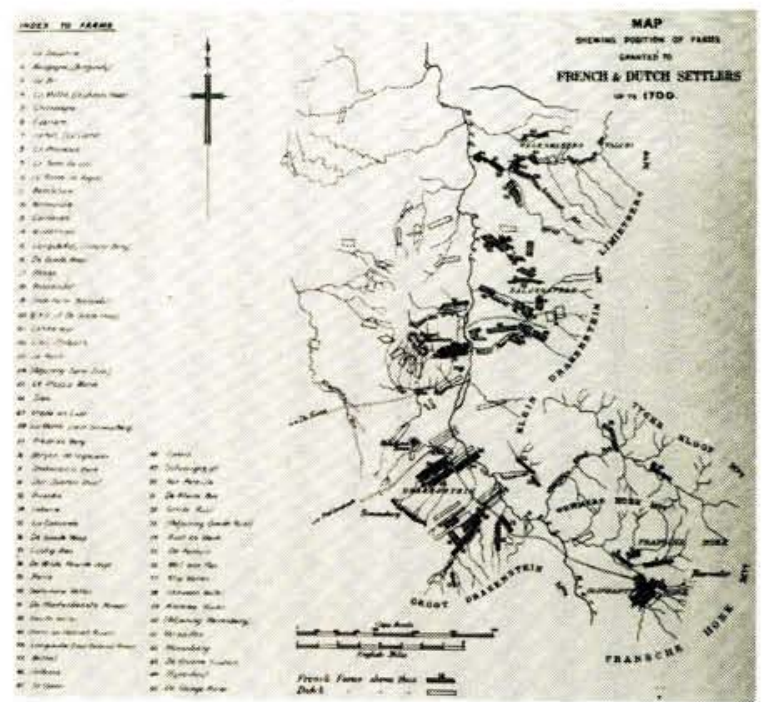

Kaart van die plase toegesê aan Franse en Nederlandse Setlaars tot en met die jaar 1700

In sy bekende publikasie The Dutch Seaborne Empire 1600-1800 (London, 1965), vestig C.R. Boxer die aandag op die gevolge van goewerneur Simon van der Stel (1679-1699) se besluit om die Franse Hugenote tussen die ander koloniste te laat woon waardeur die versmelting met die ander blanke bevolkingselemente binne twee of drie geslagte ' $n$ voldonge feit was. Met instemming haal hy dan die Nederlandse skrywer Johan Splinter (J.S. Stavorinus, 1739-1788) aan wat omstreeks $1778-1780$ in verband met die Kaapse koloniste opgemerk het:
"Although the first colonists here were composed of various nations, they are by the operation of time, now so thoroughly blended together, that they are not to be distinguished from each other; even most of such as have been born in Europe, and who have resided here for some years, have, in a manner, changed their national character, for that of this country."

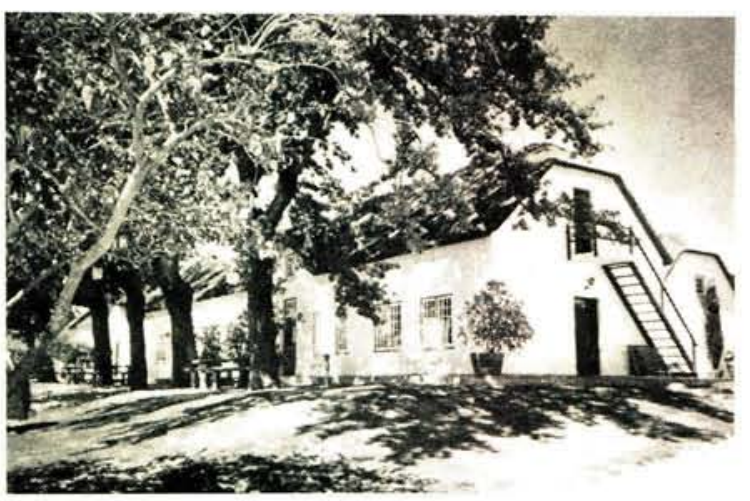

Een van die deftige wonings wat verteenwoordigend is van 'n klein deeltjie van die Hugenote nalatenskap wat steeds besigtig kan word in die pragtige wynlande van die Kaap

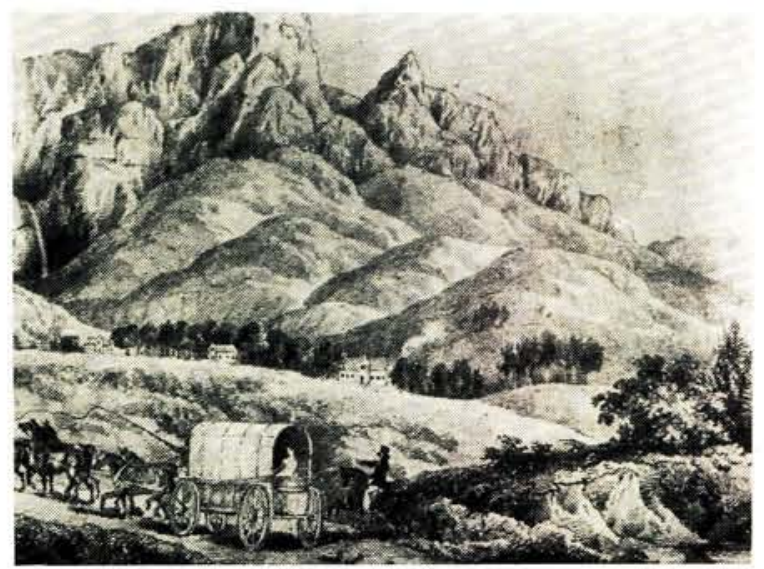

Die plaas L'Ormarins in die Drakensteinvallei. Dit het aan die Franse immigrant Jean Roi behoort wie se eiendomsreg in 1694 toegestaan is

In hierdie opsig het, ook in ons land die Franse Hugenote en hulle afstammelinge dieselfde koers as hul geloofsgenote in ander lande gevolg.

Mag hierdie beskeie bydrae die belangstellende lesers in die jaar van die derde eeufees van die aankoms van die Franse Hugenote in ons land ' $n$ mate van insig gee in die omvang van 'n grootskaalse trek ter wille van die vryheid van godsdienstige denke en die uitoefening van dié denk- 
beelde. Waar hierdie vryheidsoekers gekom het, is hulle met ope arms ontvang en het hulle hulle nuwe omgewings in velerlei opsigte verryk.

\section{Bibliografie:}

J.F. Bense, Anglo-Dutch Relations from the Earliest times to the death of William the third being an historical introduction to a dictionary of the Low-Dutch element in the English vocabulary (London, The Hague, 1925).

C.G. Botha, Die Kaapse Hugenote (Kaapstad, 1939)

C.R. Boxer, The Dutch Seaborne Empire 1600-1800 (London, 1965). Die Huisgenoot, deel XXIII, no 912, 15 September 1939 (Kaapstad, 1939).

Gereformeerde Kerkalmanak, 1940 (Potchefstroom).

Robert Lacour-Gayet, A History of South Africa (London, 1977).

H.V. Morton, In search of South Africa (London, 1948).

A. Rein, Die europäische Ausbreitung über die Erde (Erfurt, 1931).

C. Weiss, History of the French Protestant Refugees from the revocation of the Edict of Nantes to the present time (Edinburgh, London, 1954).

Generaal Piet Joubert, waarskynlik die beroemdste leier van Hugenote afkoms, was die held van die Slag van Majuba

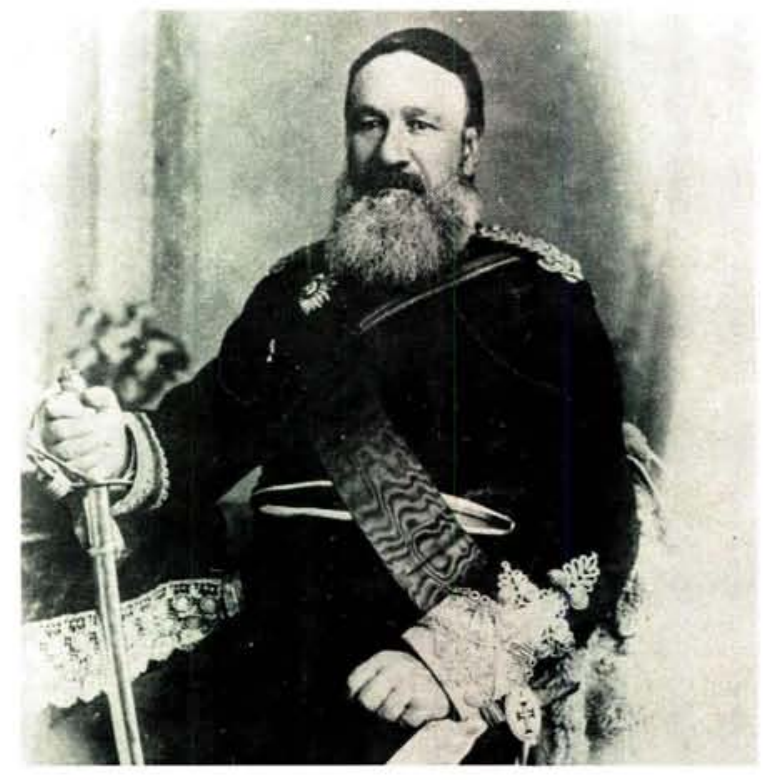

\section{HUGENOTE-BESKOUINGS}

Met verwysing na Sentra Historica V, De herroeping van het Edict van Nantes (1685) in de Franse en Nederlandse geskchiedschrijving (Amsterdam 1987, p 77) kan o.m. die volgende vermeld word:

In sy voorwoord tot hierdie publikasie van 'n drietal voordragte van Nederlandse navorsers oor die genoemde onderwerp verklaar prof dr G.J. Schutte o.m. dat slegs 'n beperkte aantal gebeurtenisse uit die ouer Europese geskiedenis bekendheid in ' $n$ breë kring geniet. Vermoedelik behoort die herroeping van die Edik van Nantes, in 1685, nog net tot dié groep. Die optrede van die Sonkoning (Lodewyk XIV) teen sy Protestantse onderdane, die lotgevalle van die Hugenote en hulle verspreiding oor die omringende lande, besit alles meer as voldoende elemente om die verbeeldingskragte te prikkel. Daar is dan ook, in die afgelope drie eeue, veel oor hierdie poging geskryf om 'n minderheidsprobleem op te los. Dit geld ook ten opsigte van die gevolge van dié poging ten opsigte van die latere politieke, sosiaalekonomiese en kulturele geskiedenis van Frankryk en Europa.

In sy bydrae oor die herroeping van die Edik van Nantes in die nuwere Franse geskiedskrywing het prof dr A. Th. van Deursen o.m. opgemerk dat die gedwonge bekering van Frankryk se Protestante ' $n$ beklemming by die navorsers laat opkom. In hierdie geval is, soos in die geval van die Jode gedurende die Tweede Wêreldoorlog, magsmiddels teen 'n bepaalde volksgroep gebruik om dié groep na die ondergang te voer sonder dat daar sprake van aanwysbare skuld was. By die Jodevervolging is die totale, liggaamlike vernietiging beoog. Die Franse Protestante kon daaraan ontkom deur hulle verlede te verloën of te vlug.

Op die vraag hoeveel Protestante daar aan die vooraand van die herroeping was, is in die verlede op totale van tussen 600000 en 2000000 ingegaan. Ongeveer 30 jaar gelede het die Franse navorser Samuel Mous tot ' $n$ totaal van 865000 in 1660 gekom.

Die geskatte bevolking van Frankryk was, in dieselfde jaar, 19000000 . Die Hugenote-minderheid was dus klein nl. 4,5\% van die totale bevolking. In provinsies soos Languedoc en Dauphinè was die totaal 370 000, maar in die grootste deel van Frankryk was die persentasie aanmerklik laer as die vroeër aanvaarde $10 \%$, aldus die reeds genoemde skrywer.

* Kol dr Jan Ploeger, SSO Argief en Navorsing, SAW, 1964-1973.

Staatshistorikus, RSA, 1973-1983 